\title{
ANTIBACTERIAL ACTIVITY TESTING OF HAND SANITIZER GEL EXTRACT OF CORIANDER (CORIANDRUM SATIVUM L.) SEEDS AGAINST STAPHYLOCOCCUS AUREUS
}

\author{
Kadek Sutri Ariyanthini ${ }^{1 *}$, Elisabeth Angelina ${ }^{1}$, Kadek Nanda Banyu Permana ${ }^{2}$, Fiorenza \\ Jocelyn Thelmalina ${ }^{1}$, I Gusti Ngurah Jemmy Anton Prasetia ${ }^{1}$ \\ ${ }^{1}$ Department of Pharmacy, Faculty of Mathematics and Science, Udayana University \\ ${ }^{2}$ Department of Informatics, Faculty of Mathematics and Science, Udayana University \\ Corresponding author email: sutriariyanthini1821@gmail.com
}

\begin{abstract}
Background: Staphylococcus aureus is a bacterium that causes bacteremia in COVID-19 pneumonitis patients. S. aureus is responsible for $80 \%$ of suppurative disease, with the skin surface as its natural habitat. So, maintaining hand hygiene during a pandemic is very important. Currently, people prefer the use of practical hand sanitizers. Most hand sanitizers contain alcohol, which has the potential to irritate. Thus, the active substance of coriander seed extract is used as a substitute for alcohol. Objective: To determine the characteristics of the gel and the concentration of coriander seed extract which gave antibacterial effect against $S$. aureus. Methods: The resulting hand sanitizer gel was then tested for characteristics and antibacterial activity against Staphylococcus aureus by the Kirby-Bauer diffusion method and analyzed by the One Way Anova-LSD method. Result: The results showed that preparations with concentrations of F1(2\%), F2(4\%), and F3(6\%) respectively had inhibition zones of $1.00 \pm 0.82$ $\mathrm{mm}, 5.00 \pm 0.41 \mathrm{~mm}$, and $5.25 \pm 1.26 \mathrm{~mm}$. Conclusion: Formulas 2 and 3 were able to inhibit the growth of $S$. aureus with moderate inhibition category. The hand sanitizer gel meets the requirements for organoleptic tests, $\mathrm{pH}$, homogeneity, dispersibility, and adhesion. However, the viscosity of the preparation did not meet the requirements.
\end{abstract}

Keywords: Coriander Seed Extract, Gel Hand Sanitizer, Antibacterial

\section{INTRODUCTION}

COVID-19 is a new disease known as severe acute respiratory syndrome due to coronavirus 2 (SARS-CoV-2). This disease has claimed thousands of lives since its spread throughout the world. Some patients need to be hospitalized, even in severe cases, intensive care is required with the support of mechanical ventilation ${ }^{[1]}$. In Indonesia, the prevention and control of this virus are still being carried out by requiring the public to comply with health protocols, one of which is maintaining hand hygiene when going out and entering a place.

DOI : https://doi.org/10.24843/JPSA.2021.v03.i02.p06
According to a study conducted by Shafran et al. (2021), COVID-19 patients had a higher rate of secondary bacterial infection than influenza patients $(12.6 \%$ vs. $8.7 \% ; \mathrm{p}=0.006$ ). Staphylococcus aureus is a bacterium that causes secondary bacterial infections in patients infected with COVID19. These bacteria can cause bacteremia or secondary pneumonia associated with death in COVID-19 pneumonitis patients ${ }^{[2,3]}$.

The alternative that is implemented in the community to kill bacteria at this time is the use of hand antiseptics (hand sanitizer). Hand sanitizer is a health product that can be used anytime and anywhere to 
kill bacteria practically without using water. Thus, we need a hand sanitizer product with active substances that can kill bacteria. One of the medicinal plants with the active substance is coriander seeds (Coriandrum sativum L.). Based on research by Hasanah and Dori (2019), coriander seed essential oil and coriander seed extract can inhibit the development of gram-positive and gramnegative bacteria. Linalool is the main component of coriander seed essential oil which has the most potential to have antibacterial activity (67.7\%). Research results from Zardini et al. (2012) also proved that coriander seed extract has antibacterial activity against Staphylococcus aureus (gram-positive) as well as Klebsiella pneumonia and Pseudomonas aeruginosa (gramnegative $)^{[4,5]}$.

Previous studies have only investigated the antibacterial activity of coriander seed extract against certain bacteria without being formulated into a preparation. Therefore, the authors are interested in researching the antibacterial activity of coriander seed extract after being formulated into a hand sanitizer gel preparation against Staphylococcus aureus and the concentration of coriander seed extract which has the most effective antibacterial activity after being formulated into a hand sanitizer gel preparation.

\section{MATERIALS AND METHODS}

This research is experimental in a laboratory. In this study, hand sanitizer gel was made from ethanol extract of coriander seeds. The resulting hand sanitizer gel was then tested for its antibacterial characteristics and activity against Staphylococcus aureus by the Kirby-Bauer diffusion method.

\section{A. Materials}

The materials used in this study were coriander seeds (Coriandrum sativum L.), 70\% ethanol (OneMed), carbopol 940 (Asland), TEA (Merck), sodium benzoate
(Merck), glycerin (PT. Brataco), distilled water, and nutrient agar (NA) (Merck).

The tools used in this study were a vacuum rotary evaporator (R1050), oven (Bender ED 400), object-glass, pH meter (Mettler Toledo FE20), analytical balance (A\&D/FX-5001), Brookfield LV viscometer (DV-E), petri dish, cotton bud, spirit lamp, micropipette, and ruler.

\section{B. Coriander Seed Extraction.}

The ethanol extract of coriander seeds was made by weighing 1000 grams of coriander seed powder and putting it in a glass jar, then adding 10 liters of $70 \%$ ethanol and then covered and soaked in conditions protected from light for 24 hours. Separate the macerate using filter paper after 24 hours. Repeat the process twice with the same solvent and the volume of solvent is half of the volume of the first solvent. Collect all the obtained macerate, then concentrate using a vacuum rotary evaporator at $70^{\circ} \mathrm{C}$ for 24 hours. To obtain a thick extract, the macerate was concentrated again using an oven at $70^{\circ} \mathrm{C}$ for 1-2 hours ${ }^{[6]}$.

\section{Gel Hand Sanitizer Formula Design Ethanol Extract Coriander Seeds (Coriandrum sativum L.)}

The hand sanitizer gel preparation in this study was made with three gel formulas containing coriander seed ethanol extract with different concentration variations, namely $2 \%, 4 \%$, and $6 \%$. Based on the research of Farid et al. (2020), a basil leaf hand sanitizer gel formulation with a mixture of carbopol 940 (1.5\%), TEA (2\%), sodium benzoate $(0.1 \%)$, glycerin $(20 \%)$, and distilled water $(100 \mathrm{~mL})$ resulted in the preparation of a good hand sanitizer ge ${ }^{[7]}$.

\section{Procedure for Making Gel Hand Sanitizer.}

The hand sanitizer gel preparation was made by developing 1 gram of carbopol in $100 \mathrm{~mL}$ of distilled water, then mixing it and adding 2 grams of TEA. Sodium benzoate is dissolved in $3 \mathrm{~mL}$ of warm 
water, then poured into a mortar. Weigh the gel base that has expanded as much as 71.9 grams and mixed with glycerin, then grind until homogeneous. Add coriander seed ethanol extract with a concentration of $2 \%$, then stir again until everything is well mixed. The preparation of gels with concentrations of $4 \%$ and $6 \%$ was carried out in the same way by weighing the gel base as much as 69.9 grams and 67.9 grams, respectively.

\section{E. Evaluation of Gel Hand Sanitizer Preparations.}

The evaluation tests carried out on the hand sanitizer gel preparation are:

a. Organoleptic Test

This test was carried out to observe changes in shape, smell, and color tested at room temperature $\left(27^{\circ} \mathrm{C}\right)^{[8]}$.

b. Homogeneity Test

This test is carried out by weighing 0.1 grams of the sample, then smeared on a glass slide. The preparation is said to be homogeneous if the preparation shows a homogeneous particle arrangement and no coarse grains are seen ${ }^{[8]}$.

c. $\mathrm{pH}$ test

Testing the $\mathrm{pH}$ of the preparation is done using a calibrated $\mathrm{pH}$ meter. Weigh the gel preparation as much as 1 gram then dissolve in $10 \mathrm{ml}$ of distilled water, stir until evenly distributed. Dip the $\mathrm{pH}$ meter into the diluted gel, let it sit for a while until the numbers on the $\mathrm{pH}$ meter-monitor stabilize. Before being tested on another gel, the tip of the $\mathrm{pH}$ meter was cleaned first with distilled water so that it was clear from the rest of the gel in the previous test. The $\mathrm{pH}$ of the preparation that meets the skin $\mathrm{pH}$ criteria is $4.5-6.5^{[9]}$.

d. Spreadability Test

This test is carried out by placing 0.5 grams of gel on a glass with a diameter of $15 \mathrm{~cm}$. Place another glass on it and leave it for 1 minute, then measure the diameter of the gel spread. Add a load of 150 grams and let stand for 1 minute, then measure a constant diameter ${ }^{[9]}$. e. Adhesion Test

This test is carried out by placing 0.25 grams of gel between 2 glass objects, then the glass object is pressed with a load of 1 $\mathrm{kg}$ on it and left for 5 minutes. After that, the glass object is placed on the tool and the load weighing 80 grams is released, the time is recorded until the glass object is released ${ }^{[9]}$.

f. Viscosity Test

The tool used to measure the viscosity of the hand sanitizer gel is a Brookfield LV viscometer. The gel was put into the container and then a spindle size 4 was attached to the viscometer and the rotor was run at a speed of $30 \mathrm{rpm}$. Record the results when the speed has shown a stable number. The viscosity value of a good gel preparation is $3,000-50,000$ centipoise $^{[10]}$.

g. Hedonic Test

A hedonic test of gel preparation was carried out on all formulas using twenty panelists. This test is done by applying gel preparation on the back of the panelist's hand. The assessment is seen from the color, texture, comfort of use, and thickness of the preparation.

h. Antibacterial Activity Test

Testing of antibacterial activity on coriander seed hand sanitizer gel using test media made by agar diffusion method (Kirby and Bauer diffusion) using wells. The way it works is as follows:

1) Mark each of the three Petri dishes used into five parts (positive control, negative control, formulas 1, 2, and 3) using a marker. The base layer was made by pouring each $10 \mathrm{~mL}$ of NA into 3 Petri dishes, then allowed to solidify. After solidification, on the surface of the layers of each petri dish, 5 wells were made which were spaced so that the observation area did not rest. Take/place the bacteria using the cotton bud in the test tube, then carefully zigzag it on the petri dish in front of the spirit lamp slowly so that the wells that will be used in the antibacterial test are not destroyed/damaged. 
2) Adding hand sanitizer gel preparations to the petri dish already labeled with the respective concentrations of $2 \%, 4 \%$, and $6 \%$ using a micropipette. Furthermore, the hand sanitizer gel preparation was inserted into the wells in a petri dish for antibacterial testing, then incubated for $1 \times 24$ hours at $37^{\circ} \mathrm{C}$. After incubation $1 \times 24$ hours, observe the inhibition zone formed. Mark using a marker on a petri dish and measure the zone of inhibition using a ruler.

Table 1. Modification of the Hand Sanitizer Formula for Coriander Seed Ethanol Extract

\begin{tabular}{ccccccc}
\hline No. & Material Names & Utility & K $(-)$ & I & II & III \\
\hline 1 & Coriander seed extract & Active substance & - & $2 \%$ & $4 \%$ & $6 \%$ \\
2 & Carbopol 940 & Gelling agent & $1 \%$ & $1 \%$ & $1 \%$ & $1 \%$ \\
3 & TEA & Alkalizing & $2 \%$ & $2 \%$ & $2 \%$ & $2 \%$ \\
4 & Sodium benzoate & Preservative & $0,1 \%$ & $0,1 \%$ & $0,1 \%$ & $0,1 \%$ \\
& & & & & & \\
5 & Glycerin & Emollient & $20 \%$ & $20 \%$ & $20 \%$ & $20 \%$ \\
6 & Aquadest $(\mathrm{ad})$ & Solvent & $100 \mathrm{~mL}$ & $100 \mathrm{~mL}$ & $100 \mathrm{~mL}$ & $100 \mathrm{~mL}$ \\
\hline
\end{tabular}

\section{RESULTS}

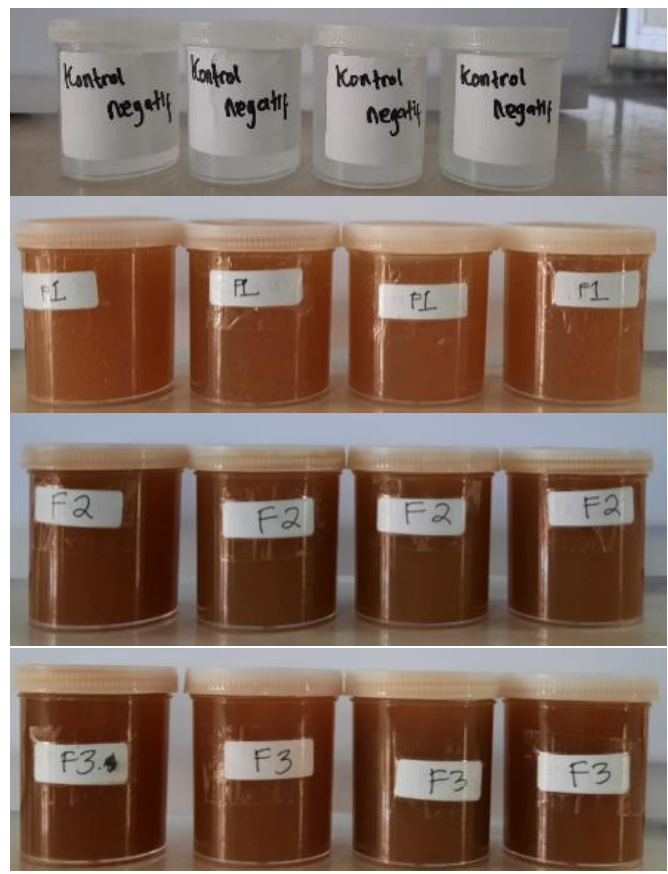

Figure 1. Preparation of Gel Hand Sanitizer Coriander Seed Ethanol Extract
Table 2. Organoleptic Test Results

\begin{tabular}{|c|c|c|c|}
\hline Formula & Colors & Smells & Forms \\
\hline K (-) & Clear white & No Smell & $\begin{array}{l}\text { Thick } \\
\text { enough }\end{array}$ \\
\hline $\mathrm{F} 1$ & $\begin{array}{l}\text { Clear } \\
\text { orange }\end{array}$ & $\begin{array}{c}\text { Coriander } \\
\text { Smell }\end{array}$ & $\begin{array}{l}\text { Thick } \\
\text { enough }\end{array}$ \\
\hline $\mathrm{F} 2$ & $\begin{array}{c}\text { Dark } \\
\text { brown }\end{array}$ & $\begin{array}{c}\text { Coriander } \\
\text { Smell }\end{array}$ & $\begin{array}{l}\text { Liquid } \\
\text { enough }\end{array}$ \\
\hline F3 & $\begin{array}{c}\text { Dark } \\
\text { chocolate }\end{array}$ & $\begin{array}{c}\text { Coriander } \\
\text { Smell }\end{array}$ & Liquid \\
\hline
\end{tabular}

Table 3. Homogeneity Test Results

\begin{tabular}{cl}
\hline Formula & Homogeneity \\
\hline K $(-)$ & No coarse particles \\
F1 & No coarse particles \\
F2 & No coarse particles \\
F3 & No coarse particles \\
\hline
\end{tabular}

Table 4. Antibacterial Test Results

\begin{tabular}{cc}
\hline Sample & $\begin{array}{c}\text { Antibacterial Test Results } \\
\text { (Mean } \pm \text { SD) }\end{array}$ \\
\hline K (+) & $9,25 \pm 2,87$ \\
K (-) & $0,00 \pm 0,00$ \\
F1 (2\%) & $1,00 \pm 0,82$ \\
F2 (4\%) & $5,00 \pm 1,41$ \\
F3 (6\%) & $5,25 \pm 1,26$ \\
\hline
\end{tabular}



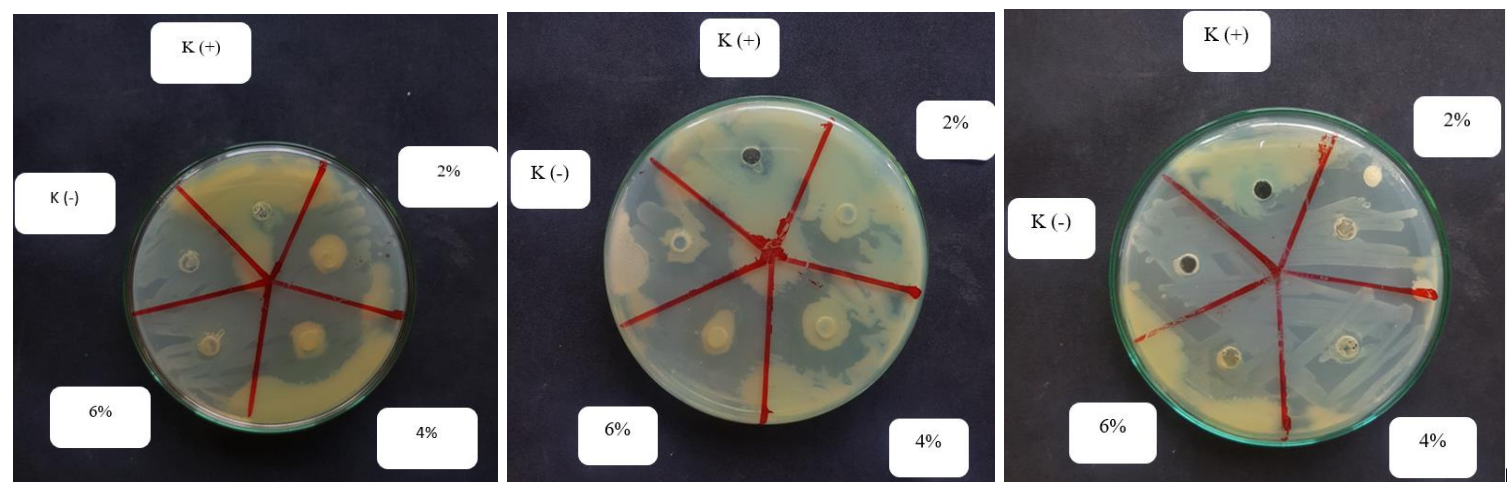

Figure 2. Antibacterial Activity Test Results

Table 5. Test Results of Adhesion, Spreadability, pH, and Viscosity of Preparations

\begin{tabular}{ccccc}
\hline Test & K $(-)$ & F1 & F2 & F3 \\
& & Mean \pm SD & & \\
\hline Adhesion & $1,28 \pm 0,24$ & $1,98 \pm 0,34$ & $1,26 \pm 0,13$ & $1,47 \pm 0,09$ \\
Spreadabili & $6,17 \pm 1,04$ & $6,40 \pm 0,53$ & $6,10 \pm 0,85$ & $6,33 \pm 0,76$ \\
ty & & & & \\
pH & $6,53 \pm 0,03$ & $6,53 \pm 0,06$ & $5,91 \pm 0,03$ & $5,93 \pm 0,02$ \\
Viskositas & $4754,33 \pm 879,42$ & $4597,33 \pm 632,19$ & $1503,33 \pm 447,14$ & $1042,33 \pm 61,44$ \\
\hline
\end{tabular}

Table 6. Hedonic Test Results

\begin{tabular}{ccccc}
\hline Parameters & Score & F1 & Sample & F3 \\
\hline Attractive gel color & Yes & 20 & 15 & 13 \\
& No & 0 & 5 & 7 \\
Smell is acceptable & Yes & 20 & 18 & 14 \\
& No & 0 & 2 & 6 \\
Convenience of Use & Yes & 19 & 15 & 12 \\
& No & 1 & 5 & 8 \\
The gel is quite thick & Yes & 19 & 15 & 10 \\
& No & 1 & 5 & 10 \\
\hline
\end{tabular}

\section{DISCUSSION}

Hand sanitizers are generally formulated into gel preparations that provide a comfortable and soft sensation on the skin $^{[11]}$. Gels are semisolid systems, consisting of suspensions made of small inorganic particles or large organic molecules that are penetrated by a liquid. If the gel mass consists of small particles that are separated from the gel system, it is called a two-phase system or magma, whereas if the organic macromolecules are evenly distributed in a liquid, the gel system is called a single-phase system ${ }^{[12]}$.

Hand sanitizer is formulated in the form of a gel because it has good aesthetic value, which is transparent, does not cause skin scars, is easy to spread evenly when applied to the skin without pressure and provides a cold sensation on the $\operatorname{skin}^{[13,14]}$. The requirements for a good gel preparation are that the gel must show a homogeneous composition and no coarse grains are seen, have a $\mathrm{pH}$ between 4.6 to 6.5 which is in accordance with the $\mathrm{pH}$ of human skin to be safe when used on the skin, have a viscosity of 3000 to $50000 \mathrm{cP}$ because Comfort when the preparation is applied is influenced by gel viscosity, comfortable dispersion in use for semisolid preparations ranging from 5-7 $\mathrm{cm}$, and good gel adhesion, which is more than 1 second $^{[15]}$.

Simplicia coriander seeds were extracted using the maceration method for 3 days by weighing 1000 grams of coriander seed powder. Coriander seed powder was then added with $5000 \mathrm{~mL}$ of $70 \%$ ethanol then covered and soaked under conditions 
protected from light for 24 hours. The macerate was separated using filter paper. The process is repeated twice with the same solvent and the volume of solvent is half of the volume of the first solvent. All the macerate was collected, then concentrated with a vacuum rotary evaporator at $70^{\circ} \mathrm{C}$ for 24 hours. Then, it was concentrated again in an oven at $70^{\circ} \mathrm{C}$ for $1-2$ hours to obtain a thick extract. The extraction results will produce ethanol extract of coriander seeds with a yield of $7.88 \%$.

The organoleptic test was carried out subjectively by looking at the color, smell, and shape of the product. In the negative control test, the visual and shape results showed that the gel was clear, odorless, and thick in shape. The sample preparation with a concentration of $2 \%$ coriander seed extract produces a clear orange color, a characteristic odor of coriander seeds, and the shape is quite thick, while for samples with a concentration of $4 \%$ and $6 \%$, the gel color becomes darker (brown to blackish brown) and tends to be darker. cloudy compared to the gel with a concentration of $2 \%$ coriander seed extract, can be seen in Figure 1. This is because the higher the concentration of the extract used, the more concentrated the color produced. However, the higher the concentration of the extract used, the more liquid the resulting gel form.

In the gel homogeneity test which was observed macroscopically, it was found that there was no separation between the solute and solvent in all samples, including the negative control. This result is an indication that the sample is homogeneous and no coarse particles are seen.

Preparation can be said to be good if it has great adhesion ability because the adhesive power aims to determine how long the contact between the hand sanitizer gel and the skin surface is. The longer the contact time with the skin, the greater the ability of the active substance to work so that the effect is also greater. Based on the data obtained, theoretically, all tested samples have met the requirements of a good gel adhesion test because it is more than 1 second $^{[15]}$. The results of the ANOVA test stated that at $\alpha=0.05$ there was a significant difference in the adhesion of the sample. The results of the LSD test stated that the stickiness of formula 1 was significantly different from the other three samples, namely negative control, formulas 2 and 3. Meanwhile, the spreadability of formula 2 was not significantly different from negative control and formula 3 .

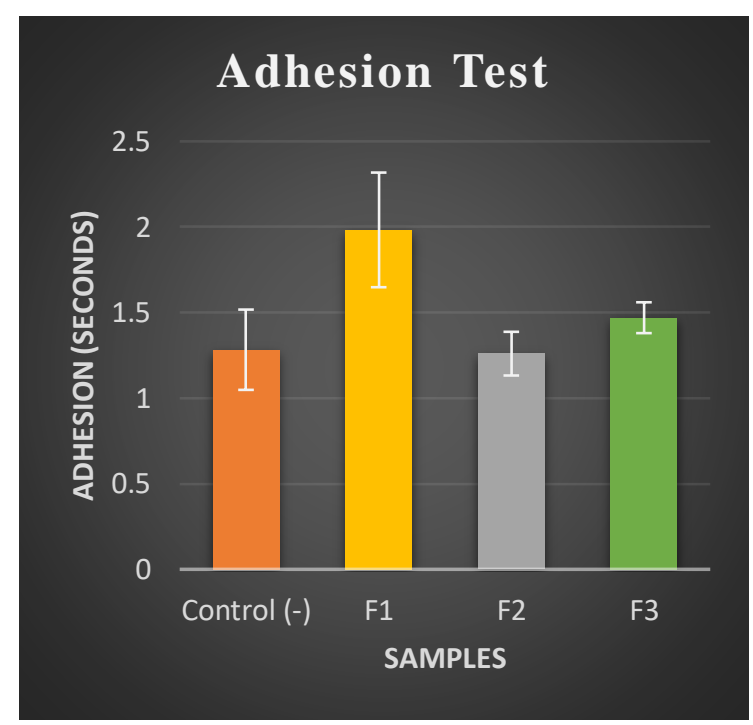

Figure 3. Graph of Adhesion Test

The dispersion test aims to see the ability of the hand sanitizer gel preparation to spread on the skin surface so that it can determine the spread of the active substances contained in the gel on the skin. This relates to the distribution of the active substance contained in the preparation. Based on the test results obtained, all the test samples are included in the category of good dispersion because they have met the requirements of the dispersibility test, where the spreadability is comfortable in use for semisolid preparations ranging from $5-7 \mathrm{~cm}^{[16]}$. The results of the ANOVA test stated that at $\alpha=0.05$ there was no significant difference in the dispersion of the sample. The results of the LSD test stated that there was no significant difference in the dispersion of all test samples. 


\section{Spreadability Test}

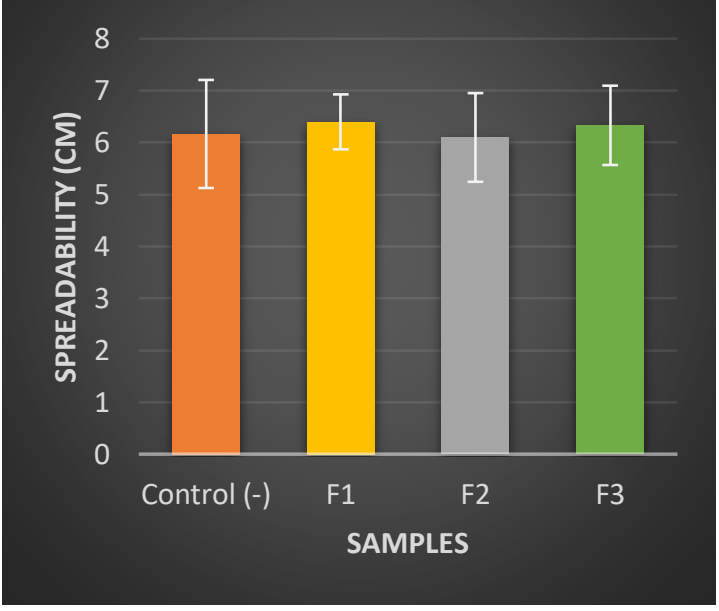

Figure 4. Graph of Spreadability Test

In testing the $\mathrm{pH}$ of the gel preparation, the $\mathrm{pH}$ ranged from 5.87 to 6.60. Testing $\mathrm{pH}$ is a critical parameter for topical preparations. This is because the $\mathrm{pH}$ in the use of cosmetic products can affect providing side effects such as irritation to the skin if the $\mathrm{pH}$ value of the preparation does not meet the specified requirements, namely 4.5-6.5. If the topical preparation has a slightly acidic $\mathrm{pH}$, it can irritate, while at an alkaline $\mathrm{pH}$ it can cause the skin to become dry. Theoretically, the $\mathrm{pH}$ range resulting from the negative control, formulas 1, 2, and 3 still meets the skin $\mathrm{pH}$ range requirements. The results of the ANOVA test stated that at $\alpha=0.05$ there was a significant difference in the $\mathrm{pH}$ of the test sample. The LSD test results stated that the $\mathrm{pH}$ of Formula 1 was significantly different from that of formulas 2 and 3 , but not significantly different from that of the negative control. While the $\mathrm{pH}$ of formula 2 was not significantly different from the $\mathrm{pH}$ of formula 3. This was because the $\mathrm{pH}$ of the extracts tended to be acidic so that with the addition of higher extracts, the $\mathrm{pH}$ would be lower.

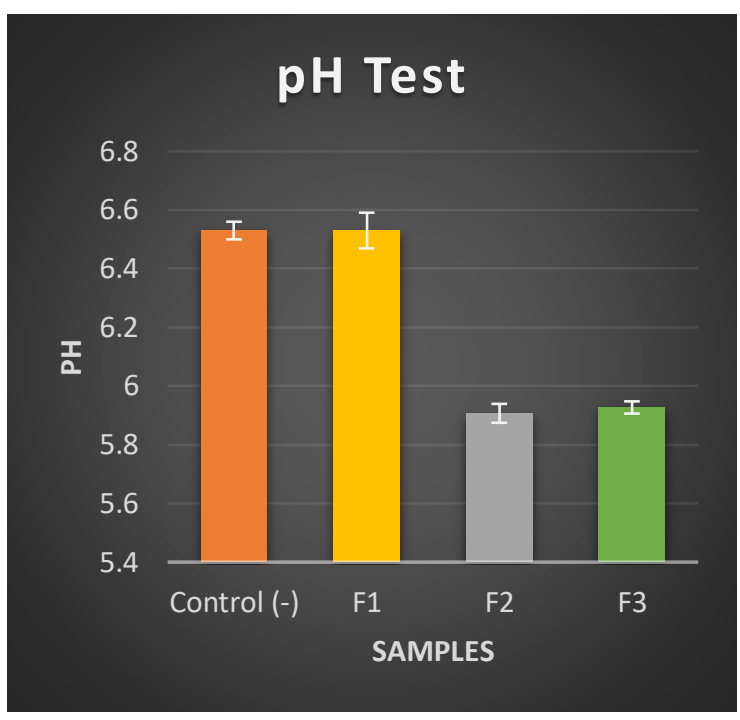

Figure 5. Graph of pH test

The viscosity of the resulting preparation showed that the higher the ethanol extract content of coriander seeds, the lower the viscosity. This was due to the increase in the concentration of the extract in the formula and the use of the same amount of carbopol and TEA for all formulas, so the preparation was more acidic. Preparations that are more acidic cause the number of ionized carboxylic groups to decrease so that there is repulsion between carboxyl groups which causes the development of the carbopol structure to decrease. This causes a decrease in the viscosity of the hand sanitizer gel along with an increase in the amount of extract. The results of the ANOVA test stated that at $\alpha=0.05$ there was a significant difference in the viscosity of the test sample. The results of the LSD test stated that the viscosity of formula 1 was significantly different from the viscosity of formulas 2 and 3, but not significantly different from the negative control. Meanwhile, the viscosity of formula 2 was not significantly different from that of formula 3. 


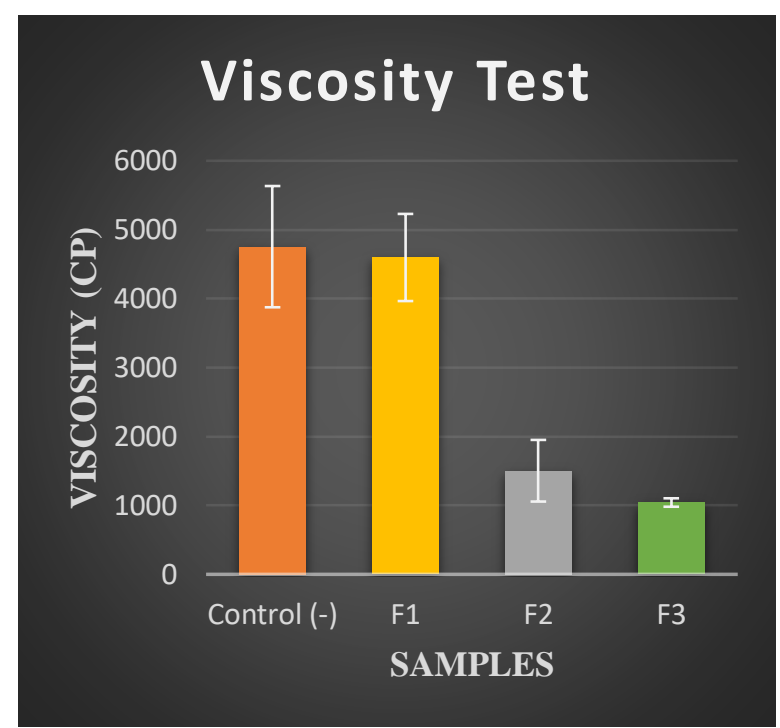

Figure 6. Graph of Viscosity Test

Based on the results of the measurement of the inhibition zone of the hand sanitizer gel of coriander seed extract (Coriandrum sativum L.) against the test bacteria can be seen in Figure 2. The measurement results of Staphylococcus aureus bacteria obtained from each concentration of coriander seed extract (Coriandrum sativum L.) are $2 \%, 4 \%$, and $6 \%$, which have different inhibitory power. At a concentration of $2 \%$ with an average value of $1.00 \pm 0.8165 \mathrm{~mm}$ and is said to be low inhibitory. Concentrations of $4 \%$ and $6 \%$ with an average inhibitory value of 5.00 $\pm 0.4142 \mathrm{~mm}$ and $5.25 \pm 1.2583 \mathrm{~mm}$, were said to be moderate inhibitors because they had an inhibitory zone between the range of 5-10 $\mathrm{mm}$. As for the negative control using a base without extract, it did not have the diameter of the inhibition zone because there was no antibacterial activity. While the positive control using hand sanitizer which is commonly used by the community has an inhibitory power of $8 \mathrm{~mm}$ which is still said to be in the medium category.

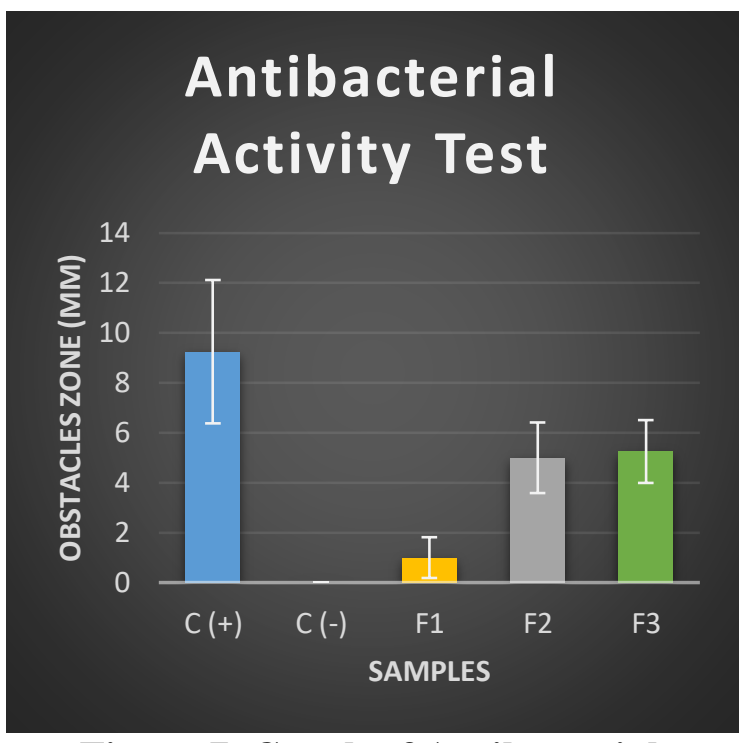

Figure 7. Graph of Antibacterial Activity Test

From the graph in Figure 7, it can be seen that the greater the concentration of coriander seeds (Coriandrum sativum L.) the greater the diameter of the inhibition zone produced. This is based on the content of flavonoids and antibacterial essential oils. Coriander seeds contain linalool essential oil which has antibacterial activity. Linalool is the compound with the highest content in coriander seed essential oil with a percentage of $8.2 \%$. Antibacterial activity in coriander essential oil has been proven in testing several types of bacteria such as Staphylococcus aureus, Staphylococcus epidermis, Pseudomonas aeruginosa, and Enterococcus coli ${ }^{[17]}$. The results of the ANOVA test stated that at $\alpha=0.05$ there was a significant difference in the antibacterial power of the test sample. The results of the LSD test stated that the antibacterial power of formula $1(2 \%)$ in killing Staphylococcus aureus was significantly different from that of the positive control, formula $2(4 \%)$ and $3(6 \%)$, but not significantly different from the negative control. Meanwhile, the antibacterial power of formula $2(4 \%)$ was not significantly different from that of formula $3(6 \%)$. 


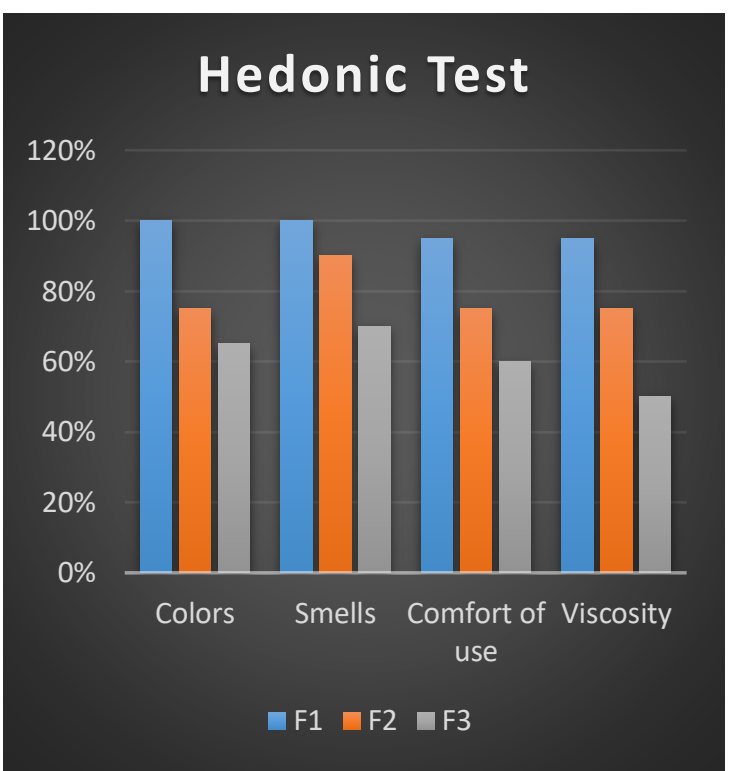

Figure 8. Graph of Hedonic Test

Based on the results of data recap using Zoho Form, the results obtained are from 20 panelists the most popular formula is formula 1. This is because in terms of the color of the gel formula 1 is more attractive than gel formula 2 and 3 . Then in terms of the thickness of the preparation, the panelists on average do not like the viscosity of the formulations of formulas 2 and 3 which are slightly liquid.

\section{CONCLUSION}

It was concluded that the coriander seed extract gel preparation (Coriandrum sativum L) had antibacterial activity in the hand sanitizer gel preparation. The ethanolic extract of coriander seeds (Coriandrum sativum L.) in the hand sanitizer preparation has an effective concentration of Staphylococcus aureus with a concentration of $4 \%$ and $6 \%$ with an average inhibition zone diameter of $5 \mathrm{~mm}$ and $5.25 \mathrm{~mm}$, respectively. However, the viscosity of the preparation does not meet the requirements of a good gel because the greater the concentration of the extract used, the more dilute the preparation will be.

\section{CONFLICT OF INTEREST}

This research was conducted independently. The author does not disclose financial or personal relationships with other people or organizations that may improperly influence the work.

\section{ACKNOWLEDGEMENT}

Thank you to those who contributed to this research, in particular to the Ministry of Education, Culture, Research, and Technology which has funded this research, and also to the Udayana University institution which has provided a forum for carrying out this research.

\section{REFERENCES}

1. Sharifipour E, Shams S, Esmkhani M, Khodadadi J, Fotouhi-Ardakani R, Koohpaei A, et al. Evaluation of bacterial co-infections of the respiratory tract in COVID-19 patients admitted to ICU. BMC Infect Dis. 2020;20(1):1-7.

2. Chandran S, Avari M, Cherian BP, Suarez C. COVID-19 associated Staphylococcus aureus cavitating pneumonia. BMJ Case Rep. 2016;14(6):1-2.

3. Shafran N, Shafran I, Ben-Zvi H, Sofer S, Sheena L, Krause I, et al. Secondary bacterial infection in COVID-19 patients is a stronger predictor for death compared to influenza patients. Sci Rep [Internet]. 2021;11(1):1-8.

4. Hasanah N, Dori RS. Daya Hambat Ekstrak Biji Ketumbar (Coriandrum Sativum L.) Terhadap Pertumbuhan Bakteri Shigella Dysenteriae Metode Cakram. Edu Masda J. 2019;3(2):11522.

5. Zardini HZ, Tolueinia B, Momeni Z, Hasani Z, Hasani M, Branch Y. Analysis of Antibacterial and Antifungal Activity of Crude Extracts From Seeds of Coriandrum sativum. Gomal J Med Sci. 2012;10(2):167-71.

6. Huljani M, Ahsanunnisa R. Pemanfaatan Ekstrak Buah Ketumbar (Coriandrum sativum L.) sebagai Larvasida Nabati Nyamuk Aedes aegypti. Pros Seminar Nasional Sains dan Teknologi Terap Univ Islam 
Negeri Raden Fatah Palembang. 2019;2(1):1-6.

7. Farid N, A N, Hamzah S, Yusuf M, Fakultas R. Aktivitas Antibakteri Hand Sanitizer Ekstrak Etanol Daun Kemangi (Ocimum Sanctum L.) Terhadap Escherichia coli dan Streptococcus aureus. Media Kesehatan Politek Kesehatan Makassar. 2020;XV(2):228-37.

8. Sulastri L, Zamzam MY. The Formulation Gel of Hand Sanitizer of Basil Leaves Ethanol Extract Concentrations of $1,5 \%, 3 \%$, and $6 \%$ with Gelling agent Carbopol 940. Medimuh. 2020;1(1):31-44.

9. Rohmani S, Kuncoro MAA. Uji Stabilitas dan Aktivitas Gel andsanitizer Ekstrak Daun Kemangi. JPSCR J Pharm Sci Clin Res. 2019;4(1):16.

10. Pertiwi RD, Kristanto J, Praptiwi GA. Uji Aktivitas Antibakteri Formulasi Gel Untuk Sariawan Dari Ekstrak Daun Saga (Abrus precatorius Linn.) Terhadap Bakteri Staphylococcus aureus. J Ilm Manuntung. 2016;2(2):239-47.

11. Corporation L. Formulation Hydroalcoholic Gels with Carbopol Polymers: Technical Data Sheet. Ohio: Lubrizol Advanced Material Inc; 2009.

12. Depkes RI. Farmakope Indonesia. IV. Jakarta: Departemen Kesehatan Republik Indonesia; 1995.

13. Wiyono AS, Mustofani D. Efektivitas Gel Ekstrak Kasar Bromelin Kulit Nanas (Ananus comosus L. Merr) Hasil Optimasi Formula Pada Tikus Yang Dibuat Luka Memar. As-Syifaa $J$ Farm. 2019;11(02):112-23.

14. Sayuti NA. Formulasi dan Uji Stabilitas Fisik Sediaan Gel Ekstrak Daun Ketepeng Cina (Cassia alata L.). $J$ Kefarmasian Indonesia. 2015;5(2):74-82.

15. Mursal ILP, Kusumawati AH, Puspasari DH. Pengaruh Variasi Konsentrasi Gelling Agent Carbopol
940 Terhadap Sifat Fisik Sediaan Gel Hand Sanitizer Minyak Atsiri Daun Kemangi (Ocimum Sanctum L.). Pharma Xplore $J$ Ilm Farm. 2019;4(1):268-77.

16. Garg, A., Aggarwal, D., Garg, S., Singla AK. Spreading of Semisolid Formulation. USA: Pharmaceutical Technology; 2002.

17. Bankar R, Kumar A, Puri S, Ali I, Sharma A, Khan IA. Chemical Composition and Antimicrobial Activity of Essential Oil from Seed of Coriandrum sativum L.. Anal Chem Lett. 2011;1(2):189-93. 